\title{
The evolution of neuroscience in Brazil - Comparative study with the other Latin America countries and BRICS - Update
}

\author{
A evolução da neurociência no Brasil - Estudo comparativo \\ com os países da América Latina e BRICS - Atualização
}

\author{
La evolución de la neurociência en Brasil - Estudio \\ comparativo com países latino-americanos y BRICS - \\ Actualización
}

Túlio Brandão Xavier Rocha ${ }^{1}$, Luciana Mendes Oliveira², Vitória Paula Dias $\mathrm{Cruz}^{3}$, César Felipe Gusmão Santiago ${ }^{4}$, Maria Andressa Neri Gonçalves Botelho ${ }^{5}$, Priscila Vieira Borges ${ }^{6}$, Lara SF Carneiro ${ }^{7,8}$, Renato Sobral Monteiro-Júnior ${ }^{9}$

1.Physiotherapist and Mechanical Engineer, master's in Physical Education, Centro Universitário FIPMoc UNIFIPMoc / Universidade Federal Fluminense - UFF. Rio de Janeiro-RJ, Brazil. https://orcid.org/00000003-0360-4515

2.Physical Education professional, master's in Physical Education, Universidade Estadual de Montes Claros - UNIMONTES / Universidade Federal Fluminense - UFF. Rio de Janeiro-RJ, Brazil.https://orcid.org/0000001-9025-6226

3.Pediatric doctor at Hospital Universitário Clemente de Faria. Montes Claros-MG, Brazil. https://orcid.org/0000-0002-3867-4612

4.Neurosurgery doctor, Neuro-oncologist, Santa Casa de Montes Claros, Faculdades Unidas do Norte de Minas - FUNORTE. Montes Claros-MG, Brazil. https://orcid.org/0000-0002-0139-967X

5.Pediatric doctor at centro Estadual de Epecialidades Médicas de Brasília de Minas. Brailia de Minas-MG, Brazil.

6.Nurse in Prefeitura de Jaíba, specialist in gerontology and mental health. Jaiba-MG, Brazil. https://orcid.org/0000-0003-1572-3802

7.Research Centre in Sports Sciences, Health Sciences and Human Development, CIDESD, GERON Research Community, Portugal. https://orcid.org/0000-0002-4385-5290

8.University Institute of Maia, ISMAI, Maia, Portugal.

9.Physical Education professional, PhD in Neuroscience, professor in Health Science post-graduation program, Universidade Estadual de Montes Claros - UNIMONTES / Universidade Federal Fluminense - UFF. Rio de Janeiro-RJ, Brazil. https://orcid.org/0000-0002-8472-262X

\section{Resumo}

Introdução. A neurociência é uma área de rápido crescimento, mas existem estudos escassos que avaliam esse crescimento de um ponto de vista crítico, avaliando e comparando com outros países o número de estudos publicados e relacionando-o à produção de conhecimento, inferida pelo número de citações. Objetivo. Comparar a produção acadêmica em neurociências no Brasil com outros países da América Latina e BRICS. Método. Foi realizada uma pesquisa no SCImago Journal e no Ranking do País sobre a produção científica dos 20 países pertencentes à América Latina e BRICS de 1996 a 2018. Os dados foram analisados por meio de estatística descritiva e análise de variância. Resultados. O Brasil apresentou a maior produção média em neurociência entre os países da América Latina $(p>0,01)$ e recebeu o maior número de citações em artigos publicados. Comparado ao BRICS, o Brasil ficou em segundo lugar em produção e citações, precedido pela China. No entanto, não foram encontradas diferenças significativas entre o número de citações obtidas em estudos brasileiros, russos e indianos. Conclusão. O Brasil é o maior produtor de conhecimento em neurociência da América Latina e o segundo entre os países do BRICS, o que mostra suas potencialidades no escopo.

Unitermos. Neurociência; Bibliometria; Mudança social; Ciência; Educação 


\begin{abstract}
Background. Neuroscience is a fast-growing area, but there are scarce studies that evaluate this growth from a critical point of view, evaluating and comparing with other countries the number of studies published and relating it to the production of knowledge, inferred by the number of citations. Objective. To compare the academic production in neurosciences in Brazil with other countries of Latin America and BRICS. Method. A survey was conducted in the SCImago Journal and in the Country Rank on the scientific production of the 20 countries belonging to Latin America and BRICS from 1996 to 2018. Data were analyzed using descriptive statistics and variance analysis. Results. Brazil presented both the highest average production in neuroscience among Latin American countries $(p>0,01)$ and has received the highest number of citations in published articles. Compared with BRICS, Brazil ranked second in both production and citations, preceded by China. However, no significant differences were found between the number of citations obtained in Brazilian, Russian and Indian studies. Conclusion. Brazil is the largest producer of knowledge in neuroscience in Latin America and the second among BRICS countries, which shows its potentialities in the scope.
\end{abstract}

Keywords. Neuroscience; Bibliometry; Social Change; Science; Education

\title{
Resumen
}

Introducción. La neurociencia es un área de rápido crecimiento, pero hay pocos estudios que evalúen este crecimiento desde un punto de vista crítico, evaluando y comparando con otros países el número de estudios publicados y relacionándolo con la producción de conocimiento, inferido por el número de citas. Objetivo. Compare la producción académica en neurociencia en Brasil con otros países de América Latina y BRICS. Método. Se realizó una encuesta en el SCImago Journal y en el Ranking de países sobre la producción científica de los 20 países pertenecientes a América Latina y BRICS entre 1996 y 2018. Los datos se analizaron mediante estadísticas descriptivas y análisis de varianza. Resultados. Brasil tuvo la producción promedio más alta en neurociencia entre los países latinoamericanos ( $p>0.01)$ y recibió el mayor número de citas en artículos publicados. En comparación con los BRICS, Brasil ocupó el segundo lugar en producción y citas, precedido por China. Sin embargo, no se encontraron diferencias significativas entre el número de citas obtenidas en estudios brasileños, rusos e indios. Conclusión. Brasil es el mayor productor de conocimiento de neurociencia en América Latina y el segundo entre los países BRICS, lo que demuestra su potencial de alcance.

Palabras clave. Neurociencia; Bibliometría; Cambio social; Ciencia; Educación

Research developed at Universidade Estadual de Montes Claros, Montes Claros - MG, Brasil

\section{INTRODUCTION}

Neuroscience appeared in 1963 in an official publication of the Neurosciences Research Program, at the Massachusetts Institute of Technology (MIT) ${ }^{1}$. It is a set of knowledge, which comprises the investigation of the nervous system and its actions onto the organic physiology, including the relationship between brain and behaviour ${ }^{2}$. Researches upon 
brain function have been calling great attention and expansion in the scientific scenario worldwide. Therefore, they have been considered by the USA government as a priority in the 1990s, which was known as the "Decade of the Brain"3,4, due to the great achievements of the human brain functions. Hence, the word "neuroscience" has evidenced itself in the production of scientific papers indexed to the main databases, e.g., the Institute for Scientific Information (ISI), MedLine and Scopus ${ }^{5}$, and it is considered an independent area in the classification of Web of Science ${ }^{6 .}$

The use of bibliometrics to assess scientific production is a fundamental tool to analyze patterns and behavior trends of several scopes of knowledge to contribute to the management of scientific development, planning and designing of national and institutional policies in a specific area, and also to evaluate the outcomes of the adopted strategies ${ }^{6,7}$. Accordingly, Brazilian scientific production relevantly increased in the last decades, especially in the subareas of biomedical scopes ${ }^{8}$.

Brazil's scientific development in neuroscience has been growing since the middle of the 20th century, due to the creation of scientific societies and research groups connected to the scope in several universities and research centers ${ }^{2}$. Ever since, Brazilian scientific production on neuroscience has experienced a relevant growth connected to the development of policies in science, technology and innovation, mainly coming from universities. Nevertheless, 
specific data on Brazilian scientific production are scarce ${ }^{5,9}$. Few studies have been evaluating scientific production in neuroscience in Brazil and Latin America5,10-12.

This study aims to map Brazil's neuroscience scope , compare the Brazilian academic production to Latin American countries and BRICS (Brazil, Russia, India, China and South Africa) in the last 21 years, thus updating previous published data ${ }^{12}$. Also, to compare the quantity of citations obtained by the publications of these countries, since the beginning of the ranking in 1996, to highlight the potentiality of this production and future perspectives, as the number of citations is an indicator of quality of academic production $^{13}$.

\section{METHOD}

A data survey has been conducted related to Brazil's scientific production and to the other 19 Latin American countries, including BRICS, from 1996 to 2018. The search process was performed in the SCImago Journal and Country Rank $^{14}$, as described in Guimarães, Monteiro-Jr and Deslandes $(2014)^{12}$.

To verify the ranking of countries comparing with the total of papers it was used the option 'Compare' and selected in field 'Subject area' the option 'Neuroscience'. It was extracted the number of documents produced by countries of Latin America (Argentina, Bolivia, Brazil, Chile, Colombia, Costa Rica, Cuba, Dominican Republic, Ecuador, El Salvador, 
Guatemala, Haiti, Honduras, Mexico, Nicaragua, Panama, Paraguay, Peru, Uruguay and Venezuela), and BRICS (Brazil, Russia, India, China, South Africa), between 1996 and 2018. The year of 1996 was chosen because it was when the database used in this study started to register data. The quantity of citations obtained by the countries has also been surveyed.

Descriptive statistics has been used with mean and standard deviation. Additionally, a one-way variance analysis with Bonferroni post hoc was used to verify the hypothesis of difference between the annual production of all the countries and the quantity of received citations. Significance level was $p \leq 0,05$. To data analysis was used the statistical software IBM ${ }^{\circledR}$ SPSS Statistics ${ }^{\circledR}$ version 23.

\section{RESULTS}

Similarly to the paper published in $2014^{12}$, there has been a significant difference $(p<0.01)$ between Brazil's production mean (1280.7 \pm 544 documents) and the other 19 countries of Latin America since 1996 to 2018. This represents a $104.15 \%$ increasing when comparing to the mean production between 1996 and 2011 (627士276 documents; Figure 1).

No significant difference has been found between Argentina (261.83 \pm 99.65 documents) and Mexico (333.91 \pm 152.14 documents $) \quad(p=1.00)$, and between Argentina and Chile (131.65 documents) $(p=0.159)$, which 


\section{Documents}
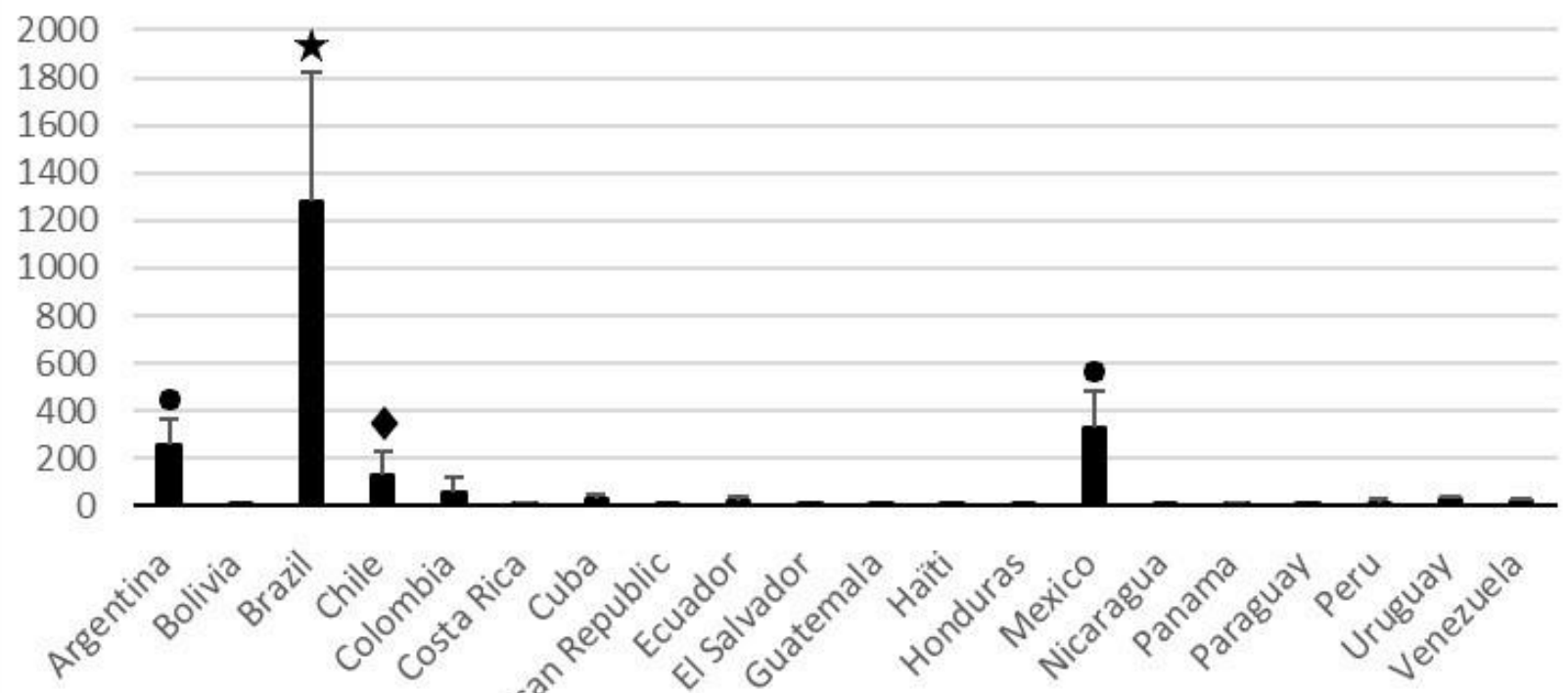

Figure 1. Mean and standard deviation of number of publications per Latin America country from 1996 to 2018.

only presented differences in relation to Brazil and Mexico $(p<0.01)$.

The mean quantity of citations obtained by the papers published in each country in that period has been also evaluated, and, again, a significant difference could be found $(p=0.01)$ between the quantity of Brazilian studies cited (20181.43 \pm 8407.95$)$ citations) when comparing to all the other Latin American countries (Figure 2).

No significant difference was found between Argentina citations (5431.39 \pm 2000.98 ) and Mexico (5439.7 \pm 2005.15$)$ $(p=1.00)$. The quantity of citations obtained by Chile's 
papers (2917.09 \pm 1388.65$)$ has not presented a statistically significant difference when compared to Colombia (1024.70 $\pm 638.54 ; p=0.308)$.

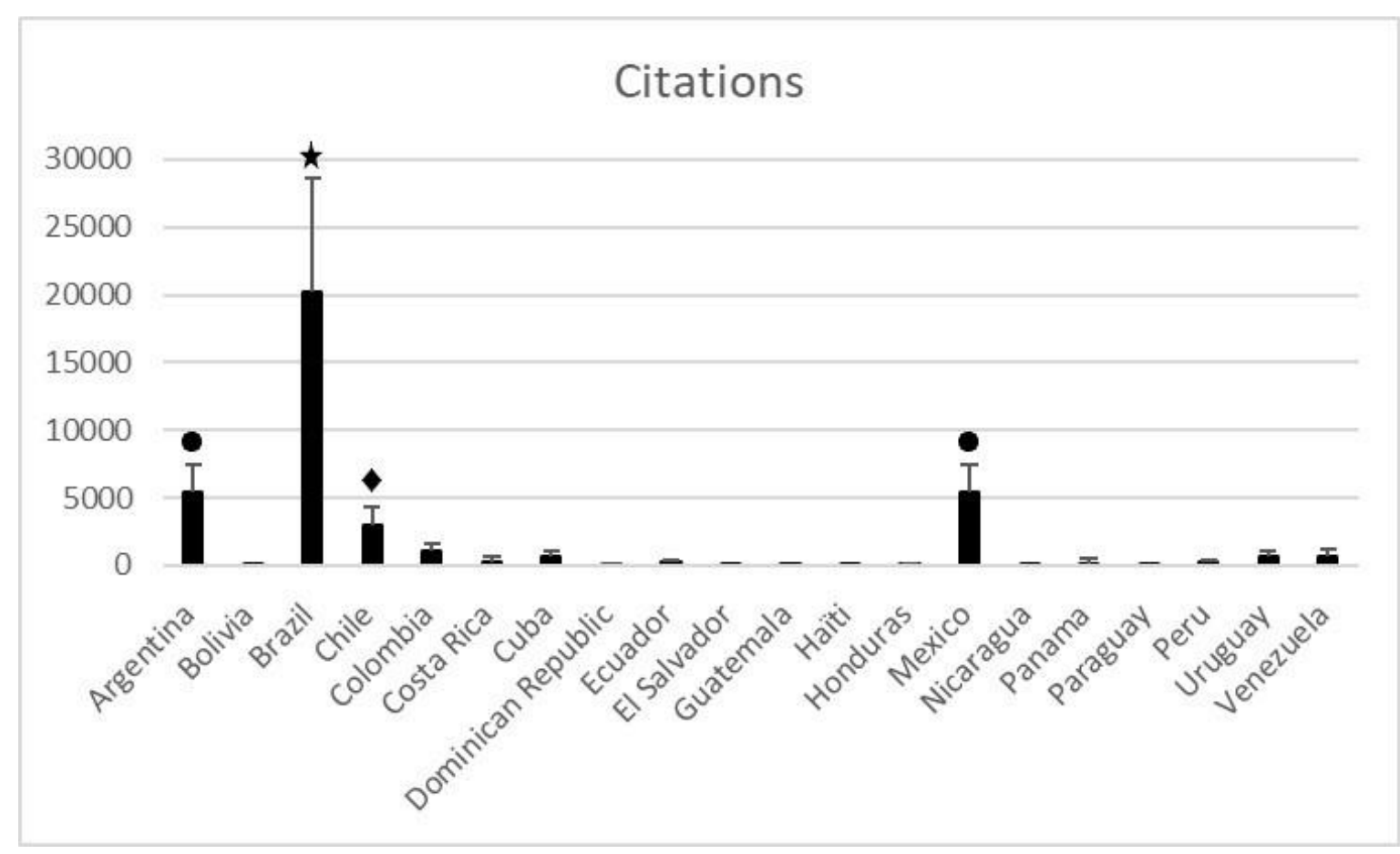

Figure 2. Mean and standard deviation of obtained citations by Latin America publications from1996 to 2018.

As in Latin America, the quantity of papers published, and the number of citations obtained by the BRICS were verified. China is the largest producer of knowledge in neuroscience (1996-2018) among the emerging countries (3265.61 \pm 3119.63 documents), with statistically significant difference $(p=0.000)$ in all the other countries belonging to the economical organization (Figure 3 ). 


\section{BRICS Documents}

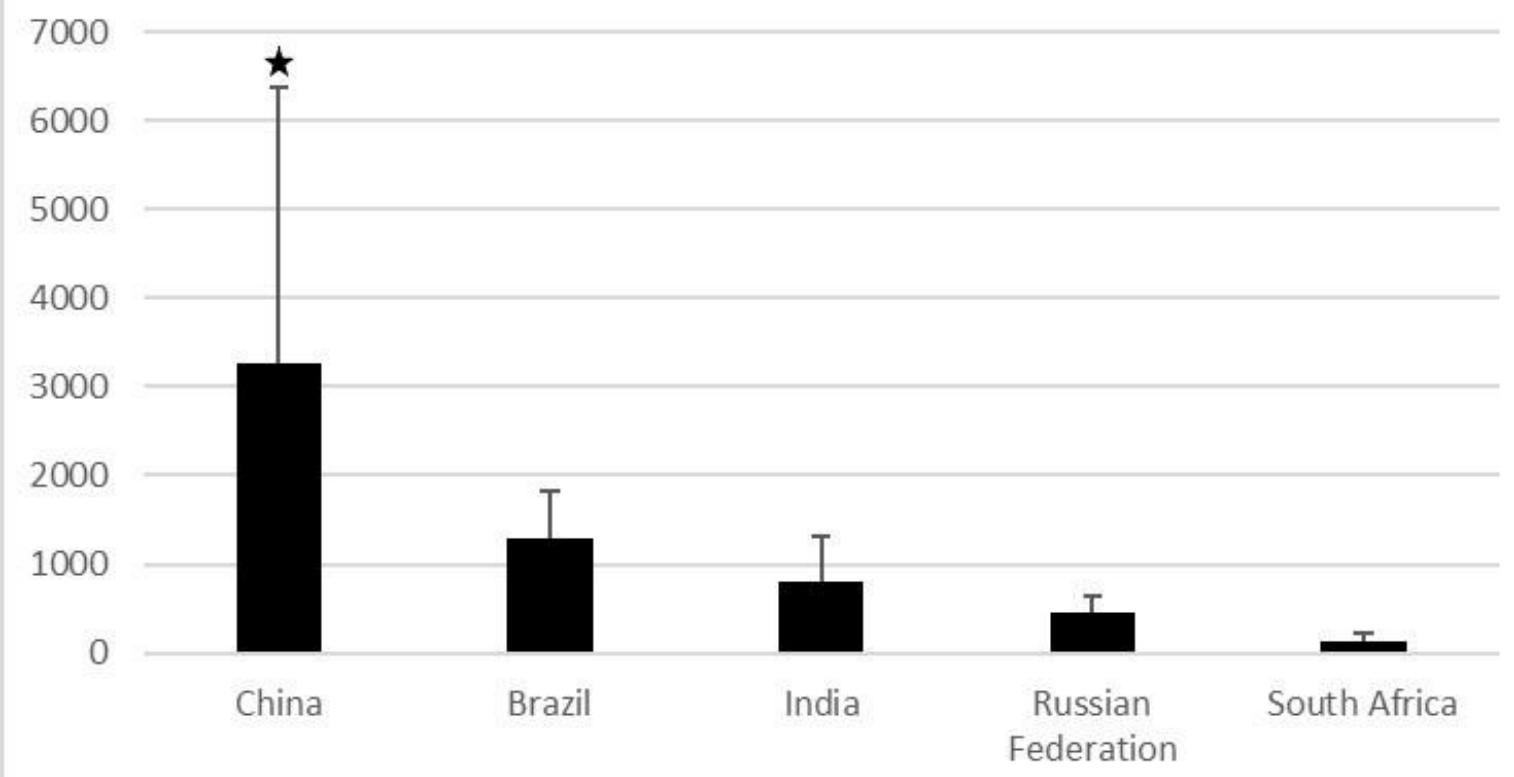

Figure 3. Mean of publication numbers per BRICS country from 1996 to 2018.

Brazil (1280.70 \pm 544.46 documents), India

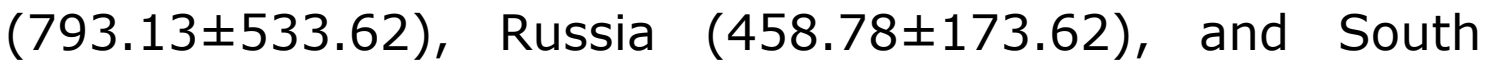
Africa (127.65 \pm 86.67$)$, when compared between them, have presented no significant differences.

When estimating the quantity of citations, China also leads (41019.04 29866.08 citations), significantly greater than all the other countries $(p=0.00)$ and Brazil was in second place (20181.43 \pm 8407.95 citations), presenting so significant difference only to India (9582.91 44382 citations) $(p=0.118 ;$ Figure 4).

However, no significant difference has been found when comparing India (9582.91 4382 citations), Russia (5197.13 $\pm 1688.85 ; \quad p=1.00)$, and South Africa $(2505.87 \pm 1089.61 ; p=0.903)$. 


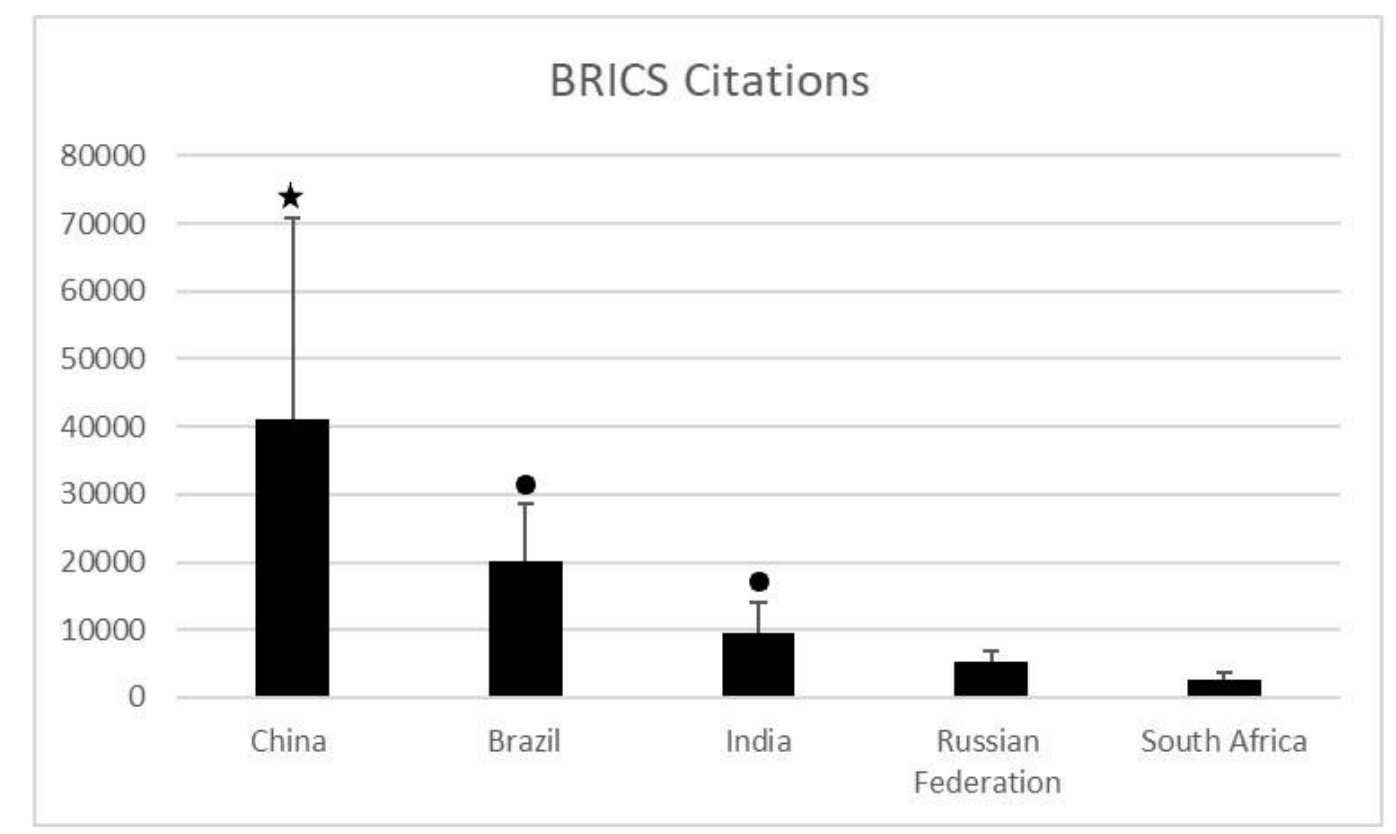

Figure 4. Mean of obtained citations by BRICS publications from 1996 to 2018.

\section{DISCUSSION}

In Latin America, Brazil is the largest annual neuroscience producer, presenting a significant mean difference in relation to all countries, followed by Mexico, Argentina, and Chile. China is the largest neuroscience producer when compared to BRICS, with three times more publications than Brazil, ranked second.

Over the last years, there has been an attempt to characterize internationally Brazil's scientific production, especially in the neuroscience scope ${ }^{15}$. Data on the profile of Brazilian researchers contributes to the design of strategies to boost scientific production, the availability of resources and to finance projects.

Among Latin America countries, Brazil holds the highest paper citation number in ISI, in psychiatry and 
psychology, in 2010; furthermore, $60 \%$ of Brazilian papers have been published in high impact factor journals, according to an evaluation of Brazil's scientific production in 2006, by the forty psychiatry magazines with the highest impact factor (IF), as reported by the Journal of Citation Report $(\mathrm{JCR})^{16}$. Researchers of Neuroscience and Psychiatry have been prominent among National Research Council (Conselho Nacional de Pesquisa - CNPq) investigators due to the higher quality of their scientific production, with approximately $70 \%$ of published articles indexed to the database Web of Science ${ }^{17 .}$

Neuroscience research has a tradition and a solid representation in our country ${ }^{2}$. Brazilian investigators distinguish themselves either in quantitative and qualitative scientific production ${ }^{17}$ and excel CNPq researchers in other knowledge scopes. This has expressively increased over the last years ${ }^{10,18-20}$.

The number of citations obtained by each periodic has been considered the most refined form of production assessment ${ }^{13}$. This study assessed also the mean quantity of obtained citations by the papers published in each country in that period of time and, once again, there has been a significant difference between the quantity of Brazilian cited studies in comparison to all the other Latin America countries. Regarding emerging countries, China also leads, however no statistically significant difference in relation to the other four BRICS countries. However, it is important to highlight that Brazil holds the second highest mean number 
of citations among these countries, which agrees with the total production. Therefore, it is reasonable to suggest that Brazilian researches in neuroscience are useful to produce new knowledge in the scope.

Despite the importance of this investigation to help the identification of neuroscience in Brazil, some issues remain open. For instance, we extract the amount of papers but not the impact factor of the journals where they were published. Other factors that might influence Brazil's better performance in the scientific production and that have not been explored correlate with institutions' incentive to research, the strengthening of graduation and postgraduation scientific programs, or the formation of research groups to work in neuroscience. The assessment of scientific production per teaching institution, state, or region, might bring a more detailed characterization of national production, even though it has not been included in this study.

Since the creation of the term "Neuroscience" by MIT researchers, the area went beyond of the original meaning that was strictly the relationship between brain and behavior. We are now interested to know how the reality is understood by the brain and how it can influence our way to think as species. It will be possible improving collaboration among neuroscientists worldwide. Maybe we can do that narrowing the relationship with our peers in Latin America. 


\section{CONCLUSION}

The breakthrough of the investigation in neuroscience characterizes an important connection with "The New Century of the Brain", with great visibility among the scientific areas in general, and particularly, in the Biomedical Sciences. Brazil evidences itself as the major scientific producer of neuroscience in Latin America and assuming a great importance within the emerging countries. This investigation aiming to show neuroscience scope in Brazil shows its potential and makes future proposals.

Subsequent approaches considering these important aspects and an analysis on the academic production converted into technology, which impacts on population's life improvement and on the development of the society, might contribute to a better understanding on this production progresses in our country.

\section{ACKNOWLEDGMENT}

The authors Túlio Brandão Xavier Rocha and Luciana Mendes Oliveira are supported by CAPES. Renato Sobral Monteiro Júnior is supported by FAPEMIG.

\section{REFERENCES}

1.Abi-Rached JM. From brain to neuro: The brain research association and the making of British neuroscience, 1965-1996. J Hist Neurosci 2012;21:189-213.http://dx.doi.org/10.1080/0964704X.2011.552413 2.Ventura DF. A report on the area of neuroscience and behavior in Brazil. Psicol Teor e Pesqui 2010;26(suppl. 1):123-9. http://dx.doi.org/10.1590/S0102-37722010000500011 
3. Menezes J, Sosa P. Conhecendo o Sistema Nervoso: Ações de Divulgação e Popularização da Neurociência Junto a Estudantes da Rede Pública de Educação Básica. Ciência e Cognição 2014;19:233-41. http://www.cienciasecognicao.org/revista/index.php/cec/article/view/ 910

4.Trópia G. Reflexões sobre o discurso na divulgação neurocientífica. Ciência \& Ensino 2008;2:1-9.

http://143.0.232.36:3537/ojs/index.php/cienciaeensino/article/viewFi le/177/144

5.Romano-Silva MA, Correa H, Oliveira MCL, Quirino IG, Colosimo EA, Martelli DR, et al. Perfil e análise da produção científica dos pesquisadores brasileiros em Neurociência Clínica. Arch Clin Psychiatry (São Paulo) 2013;40:53-8. http://dx.doi.org/10.1590/S010160832013000200001

6. Brambilla SDS. Produção científica da UFRGS representada na Web of Science Scientific (2000-2009). Perspect em Ciência da Informação 2012;17:34-50. https://www.scielo.br/pdf/pci/v17n3/a04v17n3.pdf

7.Vanz SAS. As redes de colaboração científica no Brasil (20042006)(Tese). Porto Alegre: Universidade Federal do Rio Grande do Sul, 2009.

https://www.lume.ufrgs.br/bitstream/handle/10183/17169/00071163 4.pdf

8.Guimarães JA. A pesquisa médica e biomédica no Brasil: comparações com o desempenho científico brasileiro e mundial. Cien Saude Colet 2004;9:303-27. http://dx.doi.org/10.1590/S141381232004000200009

9.Gonçalves RR, Kieling C, Bressan RA, Mari JJ, Rohde LA. The evaluation of scientific productivity in Brazil: An assessment of the mental health field. Scientometrics 2009;80:529-37. http://dx.doi.org/10.1007/s11192-008-2077-9

10.Leta J, Jacques R, Figueira I, De Meis L. Central international visibility of Brazilian psychiatric publications from 1981 to 1995. Scientometrics 2001;50:241-54. http://dx.doi.org/10.1023/A:1010569522632

11.Fiestas F, Gallo C, Poletti G, Bustamante I, Alarcón RD, Mari JJ, et al. Improving mental and neurological health research in Latin America: A qualitative study. BMC Public Health 2009;9:334. http://dx.doi.org/10.1186/1471-2458-9-334

12.Guimarães TT, Monteiro-Junior RS, Deslandes AC. A evolução da neurociência no Brasil: Uma comparação com os países da América Latina nos últimos 16 anos. Rev Neurocienc 2014;22:359-64. https://doi.org/10.4181/RNC.2014.22.03.939.6p

13.Lazzarotto Freitas J, Sampaio Rosas F, Miguel SE. Estudos métricos da informação em periódicos do Portal SciELO: visibilidade e impacto na Scopus e Web of Science. Palabra Clave (La Plata) 2017;6:21. http://dx.doi.org/10.24215/PCe021

14.SCImago (endereço na internet). SJR - SCImago Journal \& Country Rank (acessado em 2018). Disponivel em: http://www.scimagojr.com 
15. Hoppen NHF, Vanz SAS. Neurosciences in Brazil: a bibliometric study of main characteristics, collaboration and citations. Scientometrics 2016;109:121-41. http://dx.doi.org/10.1007/s11192016-1919-0

16.Martelli-Junior H, Martelli DRB, Quirino IG, Oliveira MCLA, Lima LS, Oliveira EA. Pesquisadores do CNPq na área de medicina: comparação das áreas de atuação. Rev Assoc Med Bras 2010;56:478-83. http://dx.doi.org/10.1590/S0104-42302010000400024

17.Bressan RA, Gerolin J, Mari JJ. The modest but growing Brazilian presence in psychiatric, psychobiological and mental health research: Assessment of the 1998-2002 period. Brazilian J Med Biol Res 2005;38:649-59. http://dx.doi.org/10.1590/S0100879X2005000500001

18.Saxena S, Levav I, Maulik P, Saraceno B. How international are the editorial boards of leading psychiatry journals? Lancet 2003;361:609. http://dx.doi.org/10.1016/S0140-6736(03)12528-7

19. Meis L, Velloso A, Lannes D, Carmo MS, Meis C. The growing competition in Brazilian science: Rites of passage, stress and burnout. Brazilian J Med Biol Res 2003;36:1135-41. http://dx.doi.org/10.1590/S0100-879X2003000900001

20.Nitrini R. The scientific production of Brazilian neurologists: 19952004 Arq

Neuropsiquiatr 2006;64:538-42. http://dx.doi.org/10.1590/S0004-282X2006000300037 